\title{
LEAF MORPHOANATOMY TRAITS IN WHITE GRAPEVINE CULTIVARS WITH DISTINCT GEOGRAPHICAL ORIGIN
}

\section{ANATOMIA DA FOLHA DE CULTIVARES BRANCAS DE VIDEIRA COM DISTINTA ORIGEM GEOGRÁFICA}

\author{
Generosa Teixeira ${ }^{1}$, Ana Monteiro ${ }^{2 *}$, Cristina Santos ${ }^{3}$, Carlos M. Lopes $^{2}$ \\ ${ }^{1}$ Centre for Ecology, Evolution and Environmental Changes (CE3C), Dep. Ciências Farmacológicas, Faculdade de Farmácia, Universidade de \\ Lisboa, Av. Prof. Gama Pinto, 1649-003, Lisboa, Portugal. \\ ${ }^{2}$ Centro de Investigação em Agronomia, Alimentos, Ambiente e Paisagem (LEAF), Instituto Superior de Agronomia, Universidade de Lisboa, \\ Tapada da Ajuda, 1349-017 Lisboa, Portugal. \\ ${ }^{3}$ IQV Agro Portugal SA, R. Bernardo Sequeira 16, 4715-561 Braga, Portugal.
}

*corresponding author: Tel. +351918 845 993; email: anamonteiro@isa.ulisboa.pt

(Received 22.12.2017. Accepted 09.07.2018)

\section{SUMMARY}

This study aims to compare the leaf morphoanatomical characteristics of seven Vitis vinifera subsp. vinifera white cultivars with different geographical origin, grown side by side at the same "terroir". The leaf morphoanatomical traits analyzed under light and scanning electron microscopy (SEM) showed large variability among genotypes. Significant differences between cultivars were observed in single leaf area, specific leaf area, leaf density and in the thickness of cuticle, upper and lower epidermal cells and mesophyll. Leaf dry mass per area presented a significant positive correlation with leaf density but showed no correlation with leaf thickness, results that can be explained by the quite different mesophyll structure, epidermal cells and cuticle thickness. 'Alvarinho', 'Encruzado', 'Macabeu' and 'Viosinho' were the cultivars with the highest thickness of cuticle and mesophyll tissues. Under SEM magnification three types of stomata were identified: sunken, at the same level and raised above, with the same level type presenting the higher percentage in all cultivars. Stomata density presented significant differences between cultivars, with 'Macabeu' showing the highest value and 'Alvarinho' and 'Arinto' the lowest ones. The hairs on the lower surface presented a similar woolly aspect in all cultivars. Calcium oxalate crystals, raphids and druses were visible and widely distributed in the parenchyma tissues. The observed differences in leaf traits among genotypes suggest a major role of leaf anatomy in determining grapevine capacity for coping with different environmental conditions.

\section{RESUMO}

Este estudo teve por objetivo comparar as características micromorfoanatómicas foliares de sete cultivares brancas de Vitis vinifera subsp. vinifera, com diferente origem geográfica, cultivadas lado a lado no mesmo "terroir". Os parâmetros foliares analisados, com recurso à microscopia ótica e eletrónica de varrimento, evidenciaram uma grande variabilidade entre genótipos. Observaram-se diferenças significativas entre cultivares na área foliar, área específica da folha, densidade foliar, espessura da cutícula e das células epidérmicas da página superior e inferior e do mesófilo. O peso seco por unidade de área apresentou uma correlação significativa e positiva com a densidade da folha mas não com a espessura do mesófilo, resultados que se podem explicar pelas diferenças na estrutura do mesófilo e espessura da epiderme e da cutícula. As cultivares 'Alvarinho', 'Encruzado', 'Macabeu' e 'Viosinho' foram as que apresentaram os maiores valores de espessura da cutícula e dos tecidos do mesófilo. Com recurso à microscopia eletrónica identificaram-se três tipos de estomas - enterrados, ao mesmo nível e elevados, estando o tipo de estoma ao mesmo nível presente em maior percentagem em todas as cultivares. A densidade estomática apresentou diferenças significativas entre cultivares tendo sido obtido o maior valor na cultivar 'Macabeu' e o menor nas cultivares 'Alvarinho' e 'Arinto'. O indumento da página inferior evidenciou características semelhantes nas sete cultivares. Observaram-se cristais de oxalato de cálcio, ráfides e drusas, amplamente distribuídos no parênquima folhear. As diferenças observadas entre genótipos nas características micromorfoanatómicas foliares sugerem um papel importante da anatomia da folha na determinação da capacidade da videira para se adaptar às diferentes condições ecológicas.

Key words: mesophyll, stomata, Vitis vinifera subsp. vinifera.

Palavras-chave: estomas, mesófilo, Vitis vinifera subsp. vinifera.

90

This is an Open Access article distributed under the terms of the Creative Commons Attribution License (http://creativecommons.org/licenses/by/4.0), which permits unrestricted use, distribution, and reproduction in any medium, provided the original work is properly cited. 


\section{INTRODUCTION}

The Vitaceae Juss. family comprises 14 genera and about 900 species (Soejima and Wen, 2006). Among the Vitaceae genera, Vitis L. has the greatest economic value, notably for the production of fresh grapes and wine as well as for herbal medicine and dermatology (Periyanayagam et al., 2013). Regarding the wine production, despite the existence of a high number of wine grape cultivars only a small fraction is used in commercial vineyards (Alleweldt and Dettweiler, 1994; This et al., 2006). The Mediterranean basin is the main diffusion center for this plant Taxon, namely Vitis vinifera L. subsp. vinifera. The ecological conditions that characterize Mediterranean climates - warm and dry summers and mild wet winters - has induced plant species to develop morphological and physiological mechanisms that enable them to better adapt to abiotic stresses mainly drought and heat stress (Jones, 2014). Indeed, in Mediterranean climates, where the water availability is the most important abiotic factor in limiting plant growth and yield, the adaptations to minimize transpiration are of major importance. Those adaptations are the result of the combination of several traits and mechanisms that include morphoanatomical, physiological features and hydraulic properties (Gómez-del-Campo et al., 2003; Lovisolo et al., 2010; Ben Salem-Fnayou et al., 2011; Costa et al., 2012; Palliotti et al., 2014).

Leaf morphoanatomical characteristics are functional and adaptive traits, inherent to genetic factors but also influenced by abiotic ones, which can regulate plant water use, heat dissipation and photosynthesis (Niinemets, 1999; Bosabalidis and Kofidis, 2002; Terashima et al., 2011; Palliotti et al., 2014; Tombesi et al., 2014; Carvalho et al., 2015; Montoro et al., 2016). Leaf size, by its influence on the transpiration area will affect water use and heat dissipation. Furthermore, as compared to large-leaved plants, plants with small leaves will have a better control of leaf temperature because of their higher boundarylayer conductance (Jones, 2014). Also the capacity to adjust leaf area to the water availability is an important trait for drought avoidance. Indeed, as cell size and expansion are very dependent on water availability, plants can reduce leaf area expansion when water supply declines. Moreover, plants might also adjust leaf area to the available water by promoting leaf senescence and leaf fall as a water stress response (Jones, 2014). Some authors (Tomás et al., 2012; Flexas et al., 2013) stated that mesophyll architecture, by affecting water flux in the mesophyll and water evaporation at the cell wall surface, might influence leaf water movement. Leaf thickness and density, which are the two components of leaf dry mass per area, are related with mesophyll conductance to $\mathrm{CO}_{2}$ (Niinemets et al., 2009). Indeed, in a comparison between several plant species, Tomás et al. (2013) underline the role of anatomy in mesophyll diffusion conductance and, hence, in the variability of photosynthetic capacity among species.

Plant hairs on the leaf surface originate a microenvironment around the leaf, rich in water vapor enabling water retention (Grammatikopoulous and Manetas, 1994). In addition, they reflect part of the solar radiation that reaches the leaf surface, allowing the regulation of epidermal temperature (Karabourniotis et al., 1995). Leaf hairs are also implicated in plant protection from biotic stresses as they can decrease pathogen germination rates by decreasing leaf wet ability (Brewer and Smith, 1997). The trichomes density and length varies with grapevine cultivars. A thick layer of trichomes will influence leaf radiation balance and probably help to reduce water loss by reducing leaf surface temperature and increasing the boundary layer resistance (Keller, 2010).

Cuticle thickness, structure and chemical composition are known to provide protection from desiccation. In general, as thicker the cuticle is as lower will be the cuticular conductance and, hence, the water losses (Medri and Lleras, 1980). The structure and the cuticle chemical composition also influences its capacity to retain water. Furthermore the shape of the wax plates over the cuticle, by influencing vapor path, might also play a role in the rate of water loss and, hence, affecting the epidermis waterproofing capacity (Martin and Juniper, 1970).

As compared to amphistomatous leaves, in hypostomatous leaves the presence of stomata only in the lower epidermis decreases water loss by stomatal transpiration as there is no direct incidence of solar radiation into stomata (Parkhurst, 1978; Mott et al., 1982). A high stomatal density is a feature of xerophytic plants as the presence of a huge number of stomata allows a more efficient control of leaf gas exchanges (Wilkinson, 1979). As a rule, the size and number of stomata are negatively correlated (DohenyAdams et al., 2012). There also seems to be a correlation between the number and size of stomata and the size of epidermal cells, with larger epidermal cells presenting fewer but larger stomata (Parkhurst, 1978; Mott et al., 1982; Lleras, 1997).

In Vitis leaves the stomata are located almost exclusively in the abaxial epidermis (hypostomatous) with a stomata density varying with leaf position and growth conditions (50 to 400 stomata $\mathrm{mm}^{-2}$; Keller, 2010). By its function on the regulation of leaf gas 
exchanges stomata density plays a major role on plant water use. Pratt (1974) classified stomata in three different types according to its position relatively to the level of the other epidermal cells: raised above, at the same level and sunken. The stomata type and size, width and length, are important traits for plant growth, with small, sunken or sparsely distributed stomata being considered adaptations to minimize transpiration (Jones, 2014). Sadras et al. (2012) reported that longer and wider stomata of the 'Shiraz' cultivar contributed to the enhanced plasticity of stomatal conductance under high temperatures. Serra et al. (2017) reported also a relationship between stomatal size and transpiration rate in the grapevine cultivar 'Pinotage'.

Regarding the importance of leaf morphoanatomical characteristics for plant resistance to biotic stresses, some authors (Boso et al., 2014; Atak et al., 2017) have showed that different Vitis cultivars and even clones presented different susceptibility to downy (Plasmopara viticola (Berck. \& M.A. Curtis) Berl. \& De Toni in Sacc.) and powdery mildew (Erysiphe necator Schwein.) however only a few studies associated that with differences in leaf morphology at the macro and microscopic levels. Boso et al. (2010; $2011 \mathrm{a}, \mathrm{b})$ stated that the epidermis is the first barrier for invading pathogens and trichomes can act as mechanical barriers to insects. More studies concerning less susceptible cultivars to biotic stresses are needed to further understand the impact of anatomical traits on plant resistance to diseases and pests in order to reduce the enormous pesticide consumption in Viticulture (Eurostat, 2016; Pertot et al., 2016). Pesticide reduction would be of economic and environmental importance.

Knowledge on grapevine cultivars morphoanatomical traits is also needed for the selection of genotypes better adapted to face the challenges of the climate change expected scenarios for the near future (IPCC, 2013). Despite some studies on grapevine leaf stomata morphoanatomical characteristics (Denisov, 1970; Hegedüs, 1974; Pratt, 1974; Düring, 1980; Boso et al., 2011; Monteiro et al., 2013), on trichomes (Hegedüs, 1974; Pratt, 1974), mesophyll (Pratt, 1974; Patakas et al., 2003) and on leaf area (e.g. Ben Salem-Fnayou et al., 2011; Boso et al., 2011b) only a few include relationships with physiological responses.

Until recently the macro-morphological characters were the main elements applied to the taxonomical studies. But since micro characters are less plastic than the macro ones (Metcalfe and Chalk, 1979) micro characters could be more important for taxonomical and physiological studies, in particular for understanding grapevine cultivars adaptation to different abiotic and biotic stress and, hence, to allow a better choice under the ongoing climate change conditions.

This study aims to compare the leaf morphoanatomical characteristics of seven Vitis vinifera subsp. vinifera white cultivars with different geographical origin grown at the same environmental and management conditions.

\section{MATERIAL AND METHODS}

\section{Plant material and growth conditions}

Leaves of eight-year-old field-grown grapevines (Vitis vinifera subsp. vinifera) of the white cultivars 'Alvarinho', 'Arinto', 'Encruzado', 'Moscatel de Setúbal', 'Viosinho', 'Moscatel Galego' and 'Macabeu' were studied (Table I). The grapevines were grafted onto the $1103 \mathrm{P}$ rootstock (except for 'Macabeu' and 'Moscatel Galego' - 110 R) and grown in an irrigated vineyard located at Tapada da Ajuda, Lisbon, Portugal, within the Lisbon Winegrowing Region ( $38^{\circ} 42^{\prime}$ ' 27.5' N, $9^{\circ} 10^{\prime} 56.3^{\prime}$ ', $\mathrm{W}$ and $62 \mathrm{~m}$ above sea level). The soil is a clay loam with $1.6 \%$ organic matter and a $\mathrm{pH}$ of 7.8 . The vines are spaced $1.0 \mathrm{~m}$ within and $2.5 \mathrm{~m}$ between northsouth oriented rows, trained on a vertical shoot positioning trellis with two pairs of movable wires and spur-pruned on a unilateral Royat Cordon system. All vines were uniformly pruned to $12-14$ nodes per vine. Shoots were trimmed twice, between bloom and veraison, at a height of about $1.2 \mathrm{~m}$ above the cordon. The 1.5 ha vineyard is a varietal collection where the seven studied cultivars are planted side by side ( 5 to 10 adjacent rows of 100 plants per cultivar) under the same trellis and standard cultivation management. The vineyard was drip-irrigated with drip irrigation lines in the centre of the row and consisted of pressure compensating $2.5 \mathrm{~L} / \mathrm{h}$ emitters at $1.0 \mathrm{~m}$ spacing (one per vine positioned between two adjacent vines). Irrigation started at beginning of June ( $\sim$ end of flowering) and stopped a week before harvest ( $\sim$ end of August). Watering was applied twice a week, replacing $50 \%$ of reference evapotranspiration.

For data collection, four blocks of 10 plants per cultivar were established along a central row. For the macro and microscopic observations 3-fully expanded and well exposed mature leaves per block from each cultivar were collected at veraison (end of July), from the $8-9^{\text {th }}$ node of canopy east side shoots. Leaves were inserted in plastic bags and immediately transported to the nearby laboratory. 
TABLE I

Geographical origin and characteristics of the studied grapevine cultivars (Vitis vinifera L. subsp. vinifera).

Origem geográfica e caracteristicas das cultivares de videira estudadas (Vitis vinifera L. subsp. vinifera).

\begin{tabular}{|c|c|c|c|}
\hline Grapevine cultivar & $\begin{array}{l}\text { Geographical origin or } \\
\text { Winegrowing region (WR) }\end{array}$ & Characteristics & Reference \\
\hline 'Alvarinho' & River Minho Basin, Portugal & $\begin{array}{l}\text { Susceptible to diseases (powdery and downy } \\
\text { mildews, esca), pests and water stress }\end{array}$ & $\begin{array}{l}\text { Böhm (2007); IVV } \\
\text { (2017); Boso et al. } \\
\text { (2014) }\end{array}$ \\
\hline $\begin{array}{l}\text { 'Arinto' (syn. } \\
\text { 'Pedernã' at the WR } \\
\text { Vinhos Verdes) }\end{array}$ & $\begin{array}{l}\text { Probably originated from } \\
\text { Bucelas, WR of Lisbon, } \\
\text { Portugal }\end{array}$ & $\begin{array}{l}\text { Susceptible to diseases (powdery and downy } \\
\text { mildews, excoriose) }\end{array}$ & IVV (2017) \\
\hline 'Encruzado’' & Dão WR, Portugal & $\begin{array}{l}\text { Tolerant to water stress; moderate } \\
\text { susceptibility to diseases (powdery and } \\
\text { downy mildews, Botrytis bunch rot); } \\
\text { susceptible to pests (leafhopper and } \\
\text { eriophyid mite) }\end{array}$ & $\begin{array}{l}\text { Böhm (2007); IVV } \\
\text { (2017) }\end{array}$ \\
\hline $\begin{array}{l}\text { 'Macabeu' (syn. } \\
\text { 'Viura') }\end{array}$ & Probably from Catalonia, Spain & $\begin{array}{l}\text { Median susceptibility to powdery mildew, } \\
\text { and Botrytis bunch rot; susceptible to downy } \\
\text { mildew }\end{array}$ & $\begin{array}{l}\text { IFV (2007); Santa } \\
\text { Maria et al. (2011) }\end{array}$ \\
\hline $\begin{array}{l}\text { 'Moscatel Galego' } \\
\text { (syn. 'Muscat à } \\
\text { Petits Grains', } \\
\text { France') }\end{array}$ & $\begin{array}{l}\text { Probably from Egypt. } \\
\text { Cultivated in Portugal mainly } \\
\text { in WR of Douro }\end{array}$ & $\begin{array}{l}\text { High susceptibility to powdery mildew and } \\
\text { Botrytis bunch rot; susceptible to downy } \\
\text { mildew and the European grapevine moth } \\
\text { and mites }\end{array}$ & $\begin{array}{l}\text { IFV (2007); IVV } \\
(2017)\end{array}$ \\
\hline $\begin{array}{l}\text { 'Moscatel de } \\
\text { Setúbal'(syn. } \\
\text { 'Moscatel Graúdo'; } \\
\text { 'Muscat } \\
\text { d'Alexandrie' in } \\
\text { France) }\end{array}$ & $\begin{array}{l}\text { Mediterranean, probably from } \\
\text { Southern Italy, Sardinia, Sicilia } \\
\text { or Greece. Cultivated in } \\
\text { Portugal mainly in WR of } \\
\text { Peninsula de Setúbal }\end{array}$ & $\begin{array}{l}\text { High susceptibility to powdery mildew and } \\
\text { excoriose; susceptible to downy mildew, and } \\
\text { to insects }\end{array}$ & $\begin{array}{l}\text { IFV (2007); IVV } \\
(2017)\end{array}$ \\
\hline 'Viosinho' & Douro WR, Portugal, & $\begin{array}{l}\text { High susceptibility to powdery mildew and } \\
\text { Botrytis bunch rot; moderate susceptibility to } \\
\text { downy mildew }\end{array}$ & $\begin{array}{l}\text { Böhm (2007); IVV } \\
\text { (2017) }\end{array}$ \\
\hline
\end{tabular}

\section{Leaf area, dry mass and leaf density}

For the determination of the single primary leaf area, 12 leaves were scanned at $300 \mathrm{dpi}$ and leaf area was determined from the images using the image processing software Image $®$. Those 12 leaves were then oven dried at $70^{\circ} \mathrm{C}$ for 48 hours and weighed. From these measurements dry mass per unit area and specific leaf area were calculated. Using leaf thickness data obtained from anatomical measurements, leaf density was calculated as dry mass per unit leaf mesophyll thickness (Niinemets, 1999).

\section{Anatomical measurements}

For the study of the anatomical traits (LM and SEM), from the 12 fresh leaves per cultivar, five small leaf blade sections $\left(1.5-2 \mathrm{~cm}^{2}\right)$ of each leaf were cut from the standard median portion of the lamina near the mid-rib between the primary and secondary veins. Then the leaf pieces were fixed in $5 \%$ glutaraldehyde buffered with $0.1 \mathrm{M}$ sodium phosphate, $\mathrm{pH}$ 7.0, during 4 hours at $4^{\circ} \mathrm{C}$, washed and then dehydrated by employing graded series of ethyl alcohol (Hayat, 1981). From those leaf pieces, cross-sections (8-10 $\mu \mathrm{m})$ were obtained using the paraffin histological technique at a Minot Leitz 1512 microtome (Ruzin, 1999), cleared with Chloral Hydrate and examined with a Nikon Labophot 2 photomicroscope. Crosssections images were captured with a Nikon FX-35W camera equipped with a semiautomatic Nikon PFX adapter (Nikon $\AA)$.

The light microscopy (LM) observations were focused on random fields of 24 leaf transverse sections (two per leaf) and were addressed to thickness of total lamina, mesophyll, palisade tissue, spongy tissues, upper cuticle, upper and lower epidermal cells.

For Scanning electron microscopy (SEM) analysis plant material was obtained and fixed as detailed above, critical-point dried in a Critical Point Polaron BioRad E3500 and coated with gold in a Jeol JFC1200. Observations were focused on the cross sections of 12-leaves and carried out at $15 \mathrm{kV}$ on a Jeol JSM-5220 LV scanning electron microscope equipped with a direct image acquisition system. Measurements and counts were assessed using computer-assisted image analysis.

SEM observations focused on the upper and lower epidermis surface details - type of indumentum, 
epicuticular waxes, stomata density (stomata/ $\mathrm{mm}^{2}$ ) and type and stomata cell length and width. The type of stomata followed the already mentioned nomenclature given by Pratt (1974).

\section{Data analysis}

All measurements and counts related with morphoanatomical traits were done on random fields under LM and SEM images, always at comparable leaf situations and magnifications. Quantitative characters are the average of 12 observations for macroscopic parameters and of 24 measurements for LM for thickness of total lamina, mesophyll, palisade tissue, spongy tissues, upper cuticle, upper and lower epidermal cells traits. Stomata type and density were counted and stomata cell length and width were measured from 12 lower epidermal images under SEM at $750 x$.

Statistical analysis was carried out in accordance with the SAS $^{\circledR}$ program package (SAS Institute, Cary, NC, USA). Before ANOVA, the percent stomata type was transformed using arcsine of the square root of the percentage. Differences between means were assessed by LSD test $(\mathrm{p}<0.05)$.

\section{RESULTS AND DISCUSSION}

The average values of the single primary leaf area inserted at the $8-9^{\text {th }}$ node, dry weight, specific leaf area and leaf density, are presented in Table II. 'Arinto' presented the significantly largest single leaf area, 'Viosinho' and 'Alvarinho' showed the smallest leaves while the remaining cultivars returned intermediate values with no significant differences among them. 'Arinto' presented the significantly higher leaf dry weight, followed by 'Macabeu' while 'Viosinho' showed the lowest values but not significantly different from 'Moscatel de Setúbal' and 'Alvarinho'. 'Encruzado' and 'Moscatel Galego' showed intermediate leaf dry weight values with no significant differences among them. Regarding the specific leaf area 'Moscatel de Setúbal' showed a significantly higher value than the other genotypes which presented similar values among them. The variation in leaf density was 1.8-fold, with 'Encruzado' having the least dense leaves and 'Moscatel de Setúbal' the densest ones. Specific leaf dry weight showed a significant positive correlation with leaf density ( $r=0.59, \mathrm{p}<0.001$, data not shown), but was not correlated with mesophyll thickness $(r=0.009, p>0.05$, data not shown).

\section{TABLE II}

Single leaf area, specific leaf area and leaf density for the seven white cultivars of Vitis vinifera L. subsp. vinifera, cultivated at Tapada da Ajuda, Lisbon, Portugal

Área foliar individual, área especifica da folha e densidade da folha das sete cultivares brancas de Vitis vinifera L. subsp. vinifera, plantadas na Tapada da Ajuda, Lisboa, Portugal

\begin{tabular}{|c|c|c|c|c|}
\hline Grapevine cultivars & $\begin{array}{l}\text { Single Leaf Area }{ }^{1} \\
\left(\mathrm{~cm}^{2}\right)\end{array}$ & $\begin{array}{l}\text { Dry Weight } \\
\text { (g) }\end{array}$ & $\begin{array}{l}\text { Specific Leaf Area } \\
\left(\mathrm{cm}^{2} / \mathrm{g}\right)\end{array}$ & $\begin{array}{l}\text { Leaf Density } \\
\left(\mathrm{g} / \mathrm{cm}^{3}\right)\end{array}$ \\
\hline 'Alvarinho' & $129.8(7.30) \mathrm{d}$ & $1.3(0.10) \mathrm{cd}$ & $107.0(5.06) \mathrm{b}$ & $0.57(0.04) b c$ \\
\hline ‘Arinto' & $198.2(12.53) \mathrm{a}$ & $2.1(0.15) \mathrm{a}$ & $95.3(3.95) b$ & $0.75(0.03) \mathrm{ab}$ \\
\hline 'Encruzado' & $168.0(8.05) \mathrm{b}$ & $1.6(0.09) \mathrm{bc}$ & $109.5(5.34) \mathrm{b}$ & $0.51(0.03) \mathrm{c}$ \\
\hline 'Macabeu' & $163.3(10.96) b c$ & $1.8(0.14) \mathrm{ab}$ & $94.0(4.80) \mathrm{b}$ & $0.58(0.03) b c$ \\
\hline 'Moscatel Galego' & $139.2(5.14) \mathrm{cd}$ & $1.5(0.06) b c$ & $93.0(1.33) \mathrm{b}$ & $0.80(0.11) \mathrm{a}$ \\
\hline 'Moscatel de Setúbal' & $167.6(10.76) b$ & $1.3(0.11) \mathrm{cd}$ & $139.2(7.85)$ a & $0.94(0.12) \mathrm{a}$ \\
\hline 'Viosinho' & $116.9(9.37) \mathrm{d}$ & $1.2(0.13) \mathrm{d}$ & $107.8(6.08) b$ & $0.55(0.03) \mathrm{c}$ \\
\hline Sig. & $* * *$ & $* * *$ & * & $* * *$ \\
\hline
\end{tabular}

Average of 12 full-expanded leaves from each cultivar collected at veraison, from the $8-9^{\text {th }}$ shoot node. Standard error in parenthesis. Sig.: significance; $*$, significant for $\mathrm{p}<0.05$; ***, significant for $\mathrm{p}<0.001$; in each column different letters indicate significant differences by LSD test at $\mathrm{p}<0.05$.

In all the studied cultivars the upper epidermis showed polygonal cells with straight walls, epicuticular waxes and some striate (Figure 1A). In addition, in the adaxial epidermis of the cultivars 'Alvarinho', 'Encruzado', 'Macabeu' and 'Viosinho', pearl glands were also seen (Figure 1A and 1B). In the lower epidermis the cell organization of all cultivars was similar (Figue 1C). The stomata are located only at the lower epidermis surface (hypostomatous leaves). The lower epidermis also showed the presence of one or two types of leaf hairs: i) small, multicellular and erect or slightly curved (Figure 1E) and ii) very long, probably unicellular, usually flat with a helical rolling, producing a 
network with a fluffy effect (Figure $1 \mathrm{E}$ and $1 \mathrm{~F}$ ). In the cultivars 'Viosinho' and 'Moscatel de Setúbal' only the small, multicellular, erect or slightly curved hairs were seen on the abaxial epidermis. Some of the long hairs seem to be dead cells as they do not retain their organelles. Both kinds of hairs presented an irregular distribution, no orientation and a variable density over the abaxial epidermal surface within each cultivar (Figure 1E and $1 \mathrm{~F}$ ). These features and the fluffy long hairs prevented the assessment of trichome density.
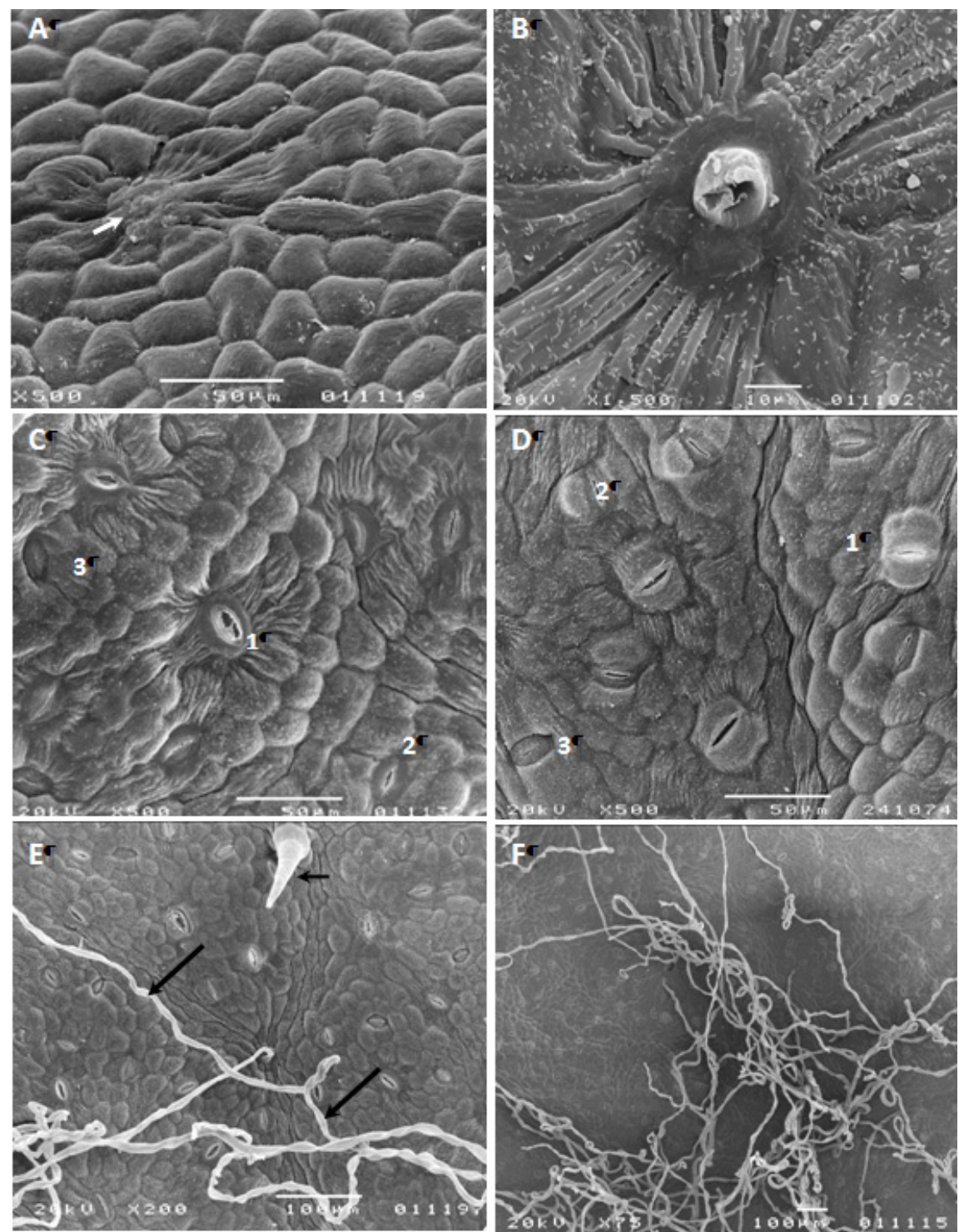

Figure 1. Leaves epidermal tissues of Vitis vinifera L. subsp. vinifera white cultivars, upper surface (A and B) and lower surface (C, D, E and F). A - 'Macabeu', with pearl gland place (arrow); B -'Alvarinho', detail of traces of a pearl gland; C -'Macabeu', different types of stomata insertion: 1- raised above; 2- same level; 3- sunken; D -'Moscatel Galego', different types of stomata insertion: 1- raised above; 2- same level; 3sunken; E -'Alvarinho', two types of protection plant hairs: small, multicellular, slightly curved (small arrow) and long, with a helical wrapping

(large arrows); F -'Encruzado', long hairs with irregular distribution and helical wrapping, originating a network with a fluffy effect.

Microfotografias da epiderme de folhas adultas de cultivares brancas de Vitis vinifera subsp. vinifera, página superior (A e B), e página inferior (C, D, E e F). A - 'Macabeu', com uma glândula perlada (seta); B - 'Alvarinho', pormenor duma glândula perlada; $C$ - 'Macabeu', diferentes tipos de estomas: 1- elevado; 2- mesmo nivel; 3- enterrado; D-'Moscatel Galego', diferentes tipos de estomas: 1- elevado; 2- mesmo nivel; 3 enterrado; E- 'Alvarinho', dois tipos de tricomas: pequeno, multicelular, ligeiramente curvo (seta pequena) e comprido, enrolado helicoidalmente (setas compridas); $F$ - 'Encruzado', tricomas compridos com uma distribuição irregular e enrolamento helicoidal, criando um efeito tomentoso. 
Considering the leaf cross sections, the studied genotypes showed dorsiventral leaves with an asymmetric mesophyll in structure limited in both upper and lower epidermis by a single layer of flattened cells (Figure 2A). The thickness of upper epidermal cells presented the significantly higher values in the cultivars 'Viosinho', 'Encruzado' and 'Macabeu' and the lowest ones in the cultivars 'Moscatel Galego' and 'Moscatel de Setúbal', while 'Arinto' and 'Encruzado' showed intermediate values. Regarding the thickness of the lower epidermal cells, 'Macabeu' presented the significantly highest values and 'Moscatel de Setúbal' the smallest one while the other cultivars returned intermediate values (Table III). The analysis of the upper cuticle thickness showed that the cultivars 'Viosinho' and 'Macabeu' presented the significantly highest values and the group of 'Alvarinho', 'Arinto', 'Moscatel Galego' and 'Moscatel de Setúbal' showed the lowest ones, while 'Encruzado' presented an intermediate upper cuticle thickness (Table III).
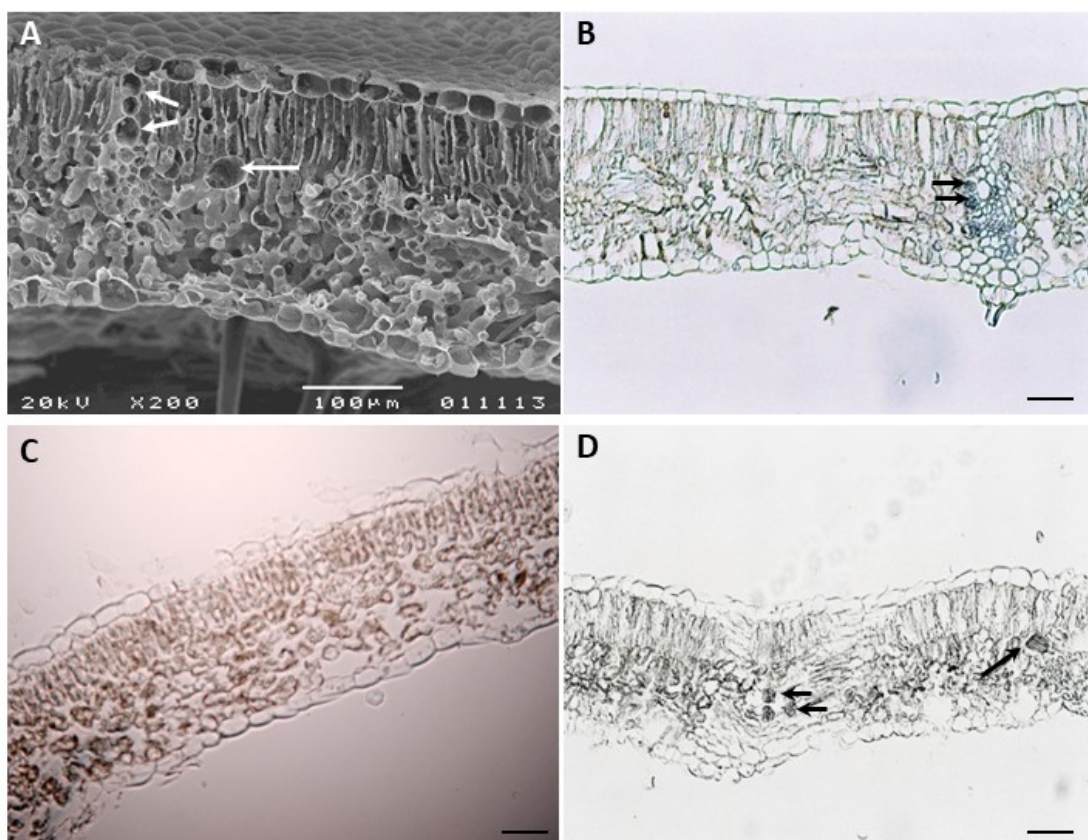

D
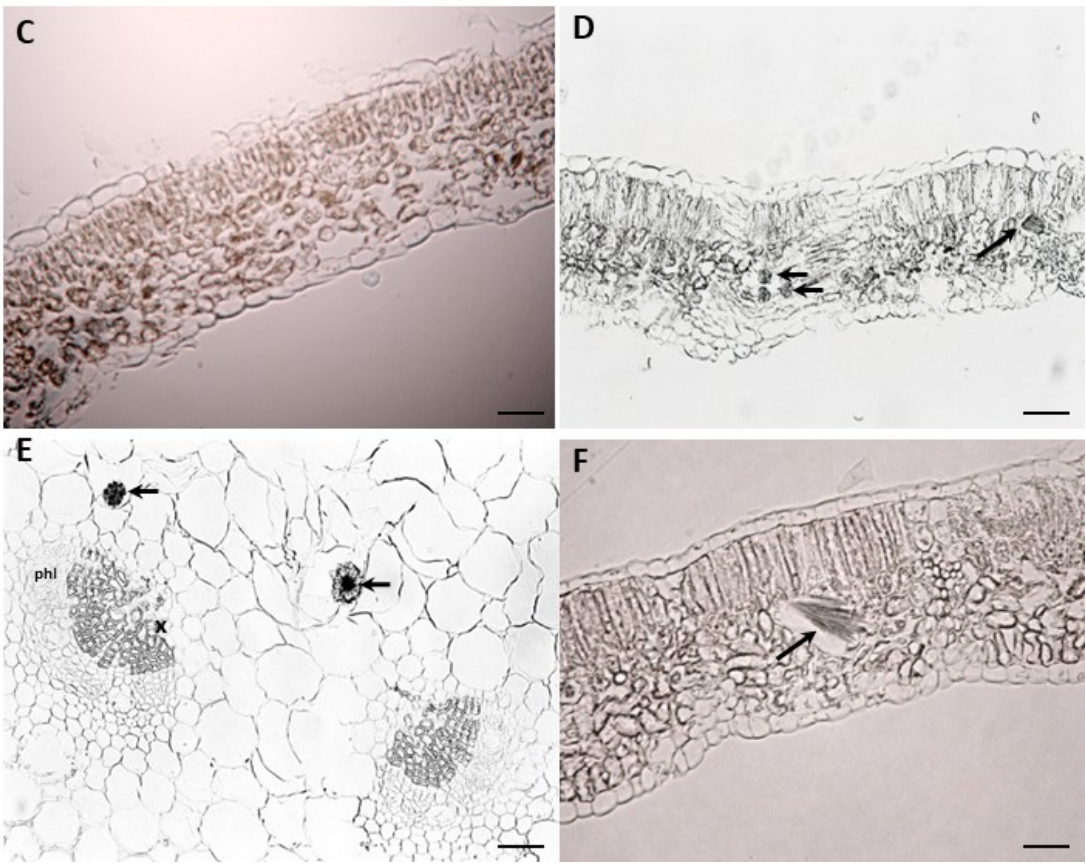

Figure 2. Leaves cross sections of Vitis vinifera L. subsp. vinifera white cultivars: SEM (A), and LM (B, C, D, E and F). A -'Viosinho', dorsiventral leaf, with bulliform cells (small arrow) and mucilage cell (large arrow); B -'Viosinho' with calcium oxalate crystals, druses type (arrows), scale bar $=50 \mu \mathrm{m} ; \mathrm{C}$-'Moscatel de Setúbal', scale bar $=30 \mu \mathrm{m}$; D -'Arinto', with both types of calcium oxalate crystals, druses (small arrows) and raphids (large arrow), scale bar $=40 \mu \mathrm{m}$; E -'Moscatel Galego', detail of leaf vein with vascular bundles (x, xylem and phl, phloem) with druses nearby (arrows), scale bar $=35 \mu \mathrm{m} ; \mathrm{F}$-'Alvarinho' with calcium oxalate crystals, raphids type, scale bar $=45 \mu \mathrm{m}$.

Corte transversal (c.t.) do mesófilo de folhas adultas das sete cultivares brancas de V. vinifera subsp. vinifera: SEM (A), e LM (B, C, D, E e F). A -'Viosinho', folha dorsiventral, com células buliformes (seta pequena) e célula mucilaginosa (seta comprida); B - 'Viosinho' com cristais de oxalato de cálcio, tipo drusas (setas); C - Moscatel de Setúbal'; D-'Arinto', com ambos os tipos de cristais de oxalato de cálcio, drusas (setas pequenas) e ráfides (setas compridas); E-'Moscatel Galego', pormenor de uma nervura com feixes vasculares $x$, xilema e phl, floema) com drusas próximo (setas); $F$ - 'Alvarinho' com cristais de oxalato de cálcio, tipo ráfides, barra $=45 \mu \mathrm{m}$. 
TABLE III

Thickness of leaf anatomical traits of the seven white cultivars of Vitis vinifera L. subsp. vinifera, cultivated at Tapada da Ajuda, Lisbon, Portugal

Espessura dos carateres anatómicos da folha das sete cultivares brancas de Vitis vinifera L. subsp. vinifera, plantadas na Tapada da Ajuda, Lisboa, Portugal

\begin{tabular}{|c|c|c|c|c|c|c|c|c|}
\hline \multirow{2}{*}{$\begin{array}{l}\text { Thickness of the } \\
\text { anatomical character } \\
(\mu \mathrm{m})\end{array}$} & \multicolumn{8}{|c|}{ Grapevine cultivars } \\
\hline & 'Alvarinho' & 'Arinto' & 'Encruzado' & 'Macabeu' & $\begin{array}{l}\text { 'Moscatel } \\
\text { Galego' }\end{array}$ & $\begin{array}{l}\text { 'Moscatel de } \\
\text { Setúbal' }\end{array}$ & 'Viosinho' & Sig. \\
\hline Total lamina & $204.9(11.50) \mathrm{a}$ & $179.5(4.34) b$ & $211.1(3.61) \mathrm{a}$ & $222.2(3.60) \mathrm{a}$ & $185.2(7.52) b$ & $127.7(4.25) \mathrm{c}$ & $217.4(4.15) \mathrm{a}$ & $* * *$ \\
\hline Upper epidermal cells & $15.8(0.93) b c$ & $15.8(0.68) b c$ & $17.1(0.90) \mathrm{abc}$ & $17.9(1.059 \mathrm{ab}$ & $15.4(0.94) \mathrm{cd}$ & $13.3(0.62) \mathrm{d}$ & $19.5(0.66)$ a & $* * *$ \\
\hline Lower epidermal cells & $18.3(0.68) b c$ & $19.5(079) \mathrm{ab}$ & $16.681 .14) \mathrm{cd}$ & $21.1(1.34) \mathrm{a}$ & $15.4(1.05) \mathrm{d}$ & $12.280 .44) \mathrm{e}$ & $18.2(0.82) b c$ & $* * *$ \\
\hline Upper cuticle & $2.1(0.10) \mathrm{c}$ & $1.9(0.11) \mathrm{c}$ & $2.2(0.08) b c$ & $2.5(0.02) \mathrm{ab}$ & $1.9(0.13) \mathrm{c}$ & $2.1(0.10) \mathrm{c}$ & $2.7(0.19) \mathrm{a}$ & $* * *$ \\
\hline Lower cuticle & $2.4(0.04) \mathrm{a}$ & $2.3(0.07) \mathrm{ab}$ & $2.1(0.10) b$ & $2.5(0.00) \mathrm{a}$ & $2.1(0.10) \mathrm{b}$ & $2.1(0.09) \mathrm{b}$ & $2.4(0.07) \mathrm{a}$ & $* * *$ \\
\hline Mesophyll & $172.1(10.77) \mathrm{a}$ & $142.4(4.16) \mathrm{b}$ & $184.1(3.63) \mathrm{a}$ & $185.7(3.73) \mathrm{a}$ & $151.9(7.66) \mathrm{b}$ & $89.7(1.34) \mathrm{c}$ & $181.0(3.72) \mathrm{a}$ & $* * *$ \\
\hline Palisade tissue & $65.5(3.93) b c$ & $59.3(2.38) \mathrm{c}$ & $73.6(1.89) \mathrm{a}$ & $69.1(2.07) \mathrm{ab}$ & $52.6(2.04) \mathrm{d}$ & $32.7(0.74) \mathrm{e}$ & $59.9(1.82) \mathrm{c}$ & $* * *$ \\
\hline Spongy tissue & $108.8(7.05) \mathrm{ab}$ & $82.1(2.14) \mathrm{c}$ & $99.4(3.329 b$ & $115.2(2.99) \mathrm{a}$ & $87.0(5.76) \mathrm{c}$ & $62.8(2.03) \mathrm{d}$ & $120.3(2.94) \mathrm{a}$ & $* * *$ \\
\hline
\end{tabular}

Average of 24 leaf transverse sections from 12 full-expanded leaves from each cultivar collected at veraison, from the 8-9 ${ }^{\text {th }}$ shoot node. Standard error in parenthesis. Sig.: significance; $* * *$, significant for $\mathrm{p}<0.001$; in each line different letters indicate significant differences by LSD test at $\mathrm{p}<0.05$.

The asymmetric mesophyll was composed of two distinct parts, one close to the upper epidermis and the other one close to the lower epidermis. The palisade parenchyma, consisted of 1 to 3 layers of relatively elongated and close cells. The spongy parenchyma showed small and loosely arranged oval to round cells and irregular intercellular air-spaces (Figure 2A, B, C, D and F).

Table III presents also the thickness values of the anatomical traits of total lamina, mesophyll, palisade tissue and spongy tissue. 'Moscatel de Setúbal' showed the significantly lowest values for all the above mentioned characters. 'Alvarinho', 'Encruzado', 'Macabeu' and 'Viosinho' showed significantly higher values of total lamina and mesophyll thickness, while 'Arinto' and 'Moscatel Galego' showed intermediate values. For the palisade tissue thickness 'Encruzado' presented the highest value and 'Moscatel de Setúbal' the lowest one, while the other cultivars returned intermediate values. Regarding the spongy tissue thickness, the cultivars 'Viosinho', 'Macabeu' and 'Alvarinho' presented the significantly higher values and 'Moscatel de Setúbal' the lowest one, while the other cultivars showed intermediate values (Table III). In general, the palisade tissue comprised approximately $40 \%$ and spongy tissue about $60 \%$ of total mesophyll (except for 'Viosinho' with $67 \%$ of spongy tissue).

The stomata density presented significant differences between cultivars, with 'Macabeu' showing the highest value, but not significantly different from 'Encruzado', 'Moscatel Galego' and 'Moscatel de Setúbal', while 'Alvarinho' and 'Arinto' presented the significantly smallest stomata density. 'Viosinho' showed intermediate stomata density between those two groups (Figure 3A).

Considering the insertion of stomata in the epidermis, the three stomata types reported by Pratt (1974), Swanepoel and Villers (1987) and Monteiro et al. (2013) coexisted in all cultivars (Figure 1C and 1D): i) raised above - the guard cells are above and each stomata is flanked by curved subsidiary cells; ii) same level - the guard cells are flattened with the subsidiary cells; and iii) sunken - the guard cells are buried between the subsidiary cells. All the three types of stomata presented a random distribution and an irregular orientation (Figure 1C, D and E).

No significant differences between cultivars were observed in the proportion of the different types of stomata (Figure 3B). In all the genotypes the dominant type of stomata was the same level stomata, which varied from $38.6 \%$ ('Macabeu') to $60.7 \%$ ('Moscatel de Setúbal') of the total stomata number. The sunken stomata presented the lower proportion with values ranging from $10.2 \%$ ('Alvarinho') to $31.5 \%$ ('Macabeu'). The raised above stomata presented a percentage in-between the other two types (Figure 3B).

In all cultivars the type of stomata which featured larger dimensions (length and width) was the raised above type whereas the same level stomata were inbetween and the sunken stomata presented always the smallest dimensions (Table IV). When analyzing the dimensions of the raised above stomata no significant differences were observed in the stomata length but stomata width showed significant differences between 
cultivars, with 'Moscatel de Setúbal' and 'Moscatel Galego' showing the highest values and 'Viosinho' the lowest one, while the other cultivars presented intermediate values. Regarding the same level stomata no significant differences were observed in the stomata length but stomata width showed also significant differences between cultivars, with 'Moscatel de Setúbal' showing the highest value and
'Arinto' the lowest one, while the other cultivars presented intermediate values. Within the sunken stomata type both stomata dimensions presented significant differences between cultivars with the 'Moscatel de Setúbal' showing the highest values and 'Encruzado' the lowest ones, while the other cultivars returned intermediate values (Table IV).
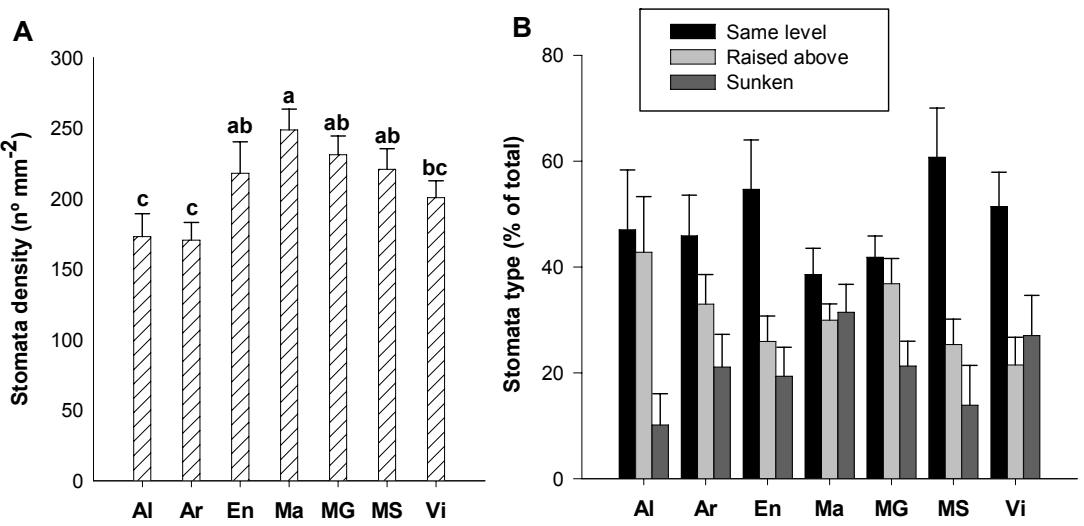

Figure 3. A - Stomata density $\left(\mathrm{n}^{\circ} \mathrm{mm}^{-2}\right)$ and B - stomata type (\% of total) for the seven white cultivars of Vitis vinifera L. subsp. vinifera, cultivated at Tapada da Ajuda, Lisbon, Portugal. Al - 'Alvarinho'; Ar - 'Arinto'; En - 'Encruzado'; Ma - 'Macabeu; MG - 'Moscatel Galego';

MS - 'Moscatel de Setúbal; Vi - 'Viosinho'. Bars indicate standard error of the mean. For each cultivar (A), means with same letters are not significantly different $(\mathrm{p}<0.05)$. Average from stomata countings of 12 SEM micrographs of 750x.

A-Densidade estomática $\left(n^{\circ} \mathrm{mm}^{-2}\right)$ e B - tipo de estoma (\% do total) das sete cultivares brancas de Vitis vinifera L. subsp. vinifera, cultivadas na Região Vitivinícola de Lisboa. Al - 'Alvarinho'; Ar - 'Arinto'; En - 'Encruzado'; Ma - 'Macabeu; MG - 'Moscatel Galego'; MS - 'Moscatel de Setúbal; Vi - 'Viosinho'. Barras indicam erro padrão da média. Para cada cultivar (A), as médias com a mesma letra não diferem significativamente $(p<0.05)$. Médias da contagem de estomas em 12 microfotografias SEM de 750x.

TABLE IV

Length and width of each stomata type for the seven white cultivars of Vitis vinifera L. subsp. vinifera, cultivated at Tapada da Ajuda, Lisbon, Portugal

Comprimento e largura de cada tipo de estoma das sete cultivares brancas de Vitis vinifera L. subsp. vinifera, plantadas na Tapada da

Ajuda, Lisboa, Portugal

\begin{tabular}{|c|c|c|c|c|c|c|c|c|}
\hline \multirow[t]{2}{*}{ Stomata dimensions } & \multicolumn{8}{|c|}{ Grapevine cultivars } \\
\hline & 'Alvarinho' & 'Arinto' & 'Encruzado' & 'Macabeu' & $\begin{array}{l}\text { 'Moscatel } \\
\text { Galego' }\end{array}$ & $\begin{array}{l}\text { 'Moscatel de } \\
\text { Setúbal' }\end{array}$ & 'Viosinho' & Sig. \\
\hline \multicolumn{9}{|l|}{ Raised above } \\
\hline Length $(\mu \mathrm{m})$ & $31.5(0.64)$ & $30.1(1.23)$ & $33.5(0.85)$ & $37.8(1.45)$ & 49.8 (1.64) & $37.3(1.47)$ & $30.0(1.86)$ & n.s. \\
\hline Width $(\mu \mathrm{m})$ & $23.1(0.52) b c$ & $20.9(0.75) \mathrm{cd}$ & $24.5(1.04) b c$ & $25.1(1.13) b$ & $30.2(1.57) \mathrm{a}$ & $31.0(1.27) \mathrm{a}$ & $19.1(1.84) \mathrm{d}$ & *** \\
\hline \multicolumn{9}{|l|}{ Same level } \\
\hline Length $(\mu \mathrm{m})$ & $26.7(0.80)$ & $26.3(0.93)$ & $27.5(0.85)$ & $28.3(1.08)$ & $27.8(1.11)$ & $28.7(0.79)$ & $26.1(0.65)$ & n.s. \\
\hline Width $(\mu \mathrm{m})$ & $17.9(0.67) b$ & $14.9(0.05) \mathrm{c}$ & $17.8(1.02) \mathrm{b}$ & $18.5(1.14) b$ & $18.6(1.04) b$ & $22.7(0.84)$ a & $16.2(0.77) b c$ & $* * *$ \\
\hline \multicolumn{9}{|l|}{ Sunken } \\
\hline Length $(\mu \mathrm{m})$ & $24.4(0.50) \mathrm{a}$ & $21.9(0.87) a b$ & $17.8(1.21) \mathrm{c}$ & $22.8(0.67) a b$ & $22.1(1.54) \mathrm{ab}$ & $24.1(1.60) \mathrm{a}$ & $20.2(0.68) b c$ & $* *$ \\
\hline Width $(\mu \mathrm{m})$ & $11.4(0.61) \mathrm{cd}$ & $12.2(0.51) b c$ & $9.0(0.73) \mathrm{d}$ & $13.8(0.68) \mathrm{b}$ & $13.6(1.08) b c$ & $17.6(0.89) \mathrm{a}$ & $11.6(0.89) \mathrm{bcd}$ & $* * *$ \\
\hline
\end{tabular}

Average of 24 measurements $(750 x)$, from 12 full-expanded leaves from each cultivar collected at veraison, from the 8-9 shoot node. Standard error in parenthesis. Sig.: significance; n. S., non-significant; **, significant for $\mathrm{p}<0.01 ; * * *$, significant for $\mathrm{p}<0.001$; in each line different letters indicate significant differences by LSD test at $\mathrm{p}<0.05$.

Idioblasts were also seen in leaf cross sections. They were widely distributed in both parenchyma tissues and two different types of calcium oxalate crystals were found inside: druses (Figure 2B, D and E) and raphids (Figure 2D and F). Besides these, a varying amount of mucilage cells could also be seen nearby (Figure 2A). Common dicot arc shaped vascular bundles were also found (Figure 2E). 
The studied cultivars with higher cuticle thickness were 'Viosinho', originated from the Portuguese Douro region and 'Macabeu', from Catalonia, Spain, regions with hot and dry Mediterranean climate (Böhm, 2007; IFV, 2007; Santa Maria et al., 2011; IVV, 2017). As compared to the other cultivars, this higher cuticle thickness can induce a lower cuticular conductance and, hence, a lower water loss for the same atmospheric demand (Medri and Lleras, 1980), indicating a likely adaptation of those two cultivars to the hot and dry ecological conditions of their geographical origin (Jones, 2014).

The leaf size is an important feature regarding water use and heat dissipation with smaller leaves being known to dissipate heat to the ambient more quickly than larger leaves because of a smaller boundary layer resistance (Jones, 2014). The cultivar which featured larger leaves was 'Arinto', probably originated from the Portuguese Bucelas winegrowing region (IVV, 2017), with an Atlantic influenced climate, while 'Viosinho', originated from the Portuguese Douro region (hot and dry climate), showed the smallest leaves.

The results obtained for the specific leaf area agree, in general, with the ones obtained for the total lamina thickness. Indeed the highest specific leaf area of 'Moscatel de Setubal' corresponds to the lower thickness of the total lamina while the lower specific leaf area of 'Macabeu' corresponds to the highest total lamina thickness. Also, the observed significant correlation between specific dry weight and leaf density in this study indicate that leaf density was the main responsible for the variation in specific dry weight as also reported by Tomás et al. (2013).

It is well known that stomatal pattern alters in response to the environmental factors such as light, air humidity, water availability and atmospheric $\mathrm{CO}_{2}$ concentration (Salisbury, 1927; Woodward and Kelly 1995; Carson and Gray, 2008). In order to avoid this possible environment influence in our study mature leaves of the same shoot node and same side of the canopy were analysed. Hence, the observed differences on stomata features (density, type and dimensions) maybe considered a genetic adaptation to the environmental conditions of their geographical origin. For instance, the higher stomatal density showed by 'Macabeu' (Catalonia, Spain) and the lower stomata dimensions presented by 'Viosinho' (originated from the Mediterranean dry climate of Douro region), features that minimize transpiration (Jones, 2014; Serra et al., 2017), seems to be an adaptation of those cultivars to water stress.

All cultivars displayed upper and lower unistratified epidermal cells with thin walls and a thin cuticle.
They had almost the same rectangular or slightly polygonal cell shape, features that are similar to those reported by Boso et al. (2010) and Monteiro et al. (2013). However these differences in transverse epidermal cell surface values do not seem to indicate an influence of the cultivars geographical origin. Some authors have pointed out that larger cellular lumen might be involved in water storage, which may have some physiological significance (Esau, 1977; Dickison, 2000). Salem-Fnayou et al. (2010) observed that under heat stress the grapevine cultivars 'Razegui' and 'Muscat Italia' exhibited elongated convex epidermal cells with a less sinuous shape than those of control leaves not submitted to heat stress.

The leaf hairs observed in the lower epidermis might have implications in epidermal temperature (Karabourniotis et al., 1995) but not in the tolerance to biotic stresses (Table I). Considering that mesophyll features are associated with the susceptibility to downy mildew (Boso et al., 2014), the highest thickness of the mesophyll, palisade and spongy tissue features measured in 'Alvarinho' can explain its known susceptibility to downy mildew (Table I).

The presence of calcium oxalate crystals in the foliar parenchyma can promote a more uniform distribution of light throughout the mesophyll, improving the photosynthetic rate (He et al., 2014). However, this feature may be related to the plant needs for large amounts of light, since the crystals prisms can increase the light interception and therefore, the photosynthetic rate, as light will be more evenly distributed around the mesophyll (Metcalfe and Chalk, 1979). Furthermore, according to Tooulakou et al. (2016), crystal degradation can provide subsidiary carbon for photosynthetic assimilation, especially under drought conditions. The crystals can also provide mechanical support and physical and chemical protection against herbivores (Metcalfe and Chalk, 1979; Prychid and Rudall, 1999; Nakata, 2003).

\section{CONCLUSIONS}

In this work significant differences among genotypes in leaf traits were observed indicating that leaf anatomy can play an important role in determining grapevine capacity for coping to specific environments. In particular, the genotypes that showed small leaves, high leaf density and high stomata density, small and/or sunken stomata may have a comparative advantage in dry and hot regions to support drought stress. The cultivars 'Viosinho' and 'Macabeu' revealed most of those xeromorphic leaf anatomical features while 'Alvarinho' and 
'Arinto', in general, tend to present more mesophytic leaf features. These observations pointed out to a likely relationship with their geographical origin however data from the cultivars 'Encruzado', 'Moscatel Galego'and 'Moscatel de Setúbal', do not allow to generalize this statement. Further studies are needed to confirm the suggested association between some of these leaf traits - specific dry weight, leaf density, mesophyll structure and stomata type, for

\section{REFERENCES}

Alleweldt G., Dettweiler-Münch E., 1994. The genetic resources of Vitis. world list of grapevine collections. Institut für Rebenzüchtung Geilweilerhof. 2nd edition.

Atak A., Akkurt M., Polat Z., Celik H., Kahraman K.A., Akgül D.S., Özer N., Söylemezoğlu G., Sire G., Eibach R., 2017. Susceptibility to downy mildew (Plasmopara viticola) and powdery mildew (Erysiphe necator) of different Vitis cultivars and genotypes. Ciência Téc. Vitiv., 32(1), 23-32.

Ben Salem-Fnayou A, Bouamama B, Ghorbel A, Mliki A., 2011 Investigations on the leaf anatomy and ultrastructure of grapevine (Vitis vinifera) under heat stress. Microsc. Res. Tech., 74(8), 75662.

Böhm J., 2007. Portugal vitícola. O grande livro das castas. Chaves Ferreira - Publicações S.A., Lisboa. 230 pp

Bosabalidis A.M., Kofidis G., 2002. Comparative effects of drought stress on leaf anatomy of two olive cultivars. Pl. Sc., 163, 375-379.

Boso S., Allonso-Villaverde V., Gago P., Santiago B.J.L., Martínez M.C., 2011a Susceptibility of 44 grapevine (Vitis vinifera L.) cultivars to downy mildew in the field. Aust. J. Grape Wine Res., 17, 304-400.

Boso S., Alonso-Villaverde V., Gago P., Santiago J.L., Martínez M.C., 2014 Susceptibility to downy mildew (Plasmopara viticola) of different Vitis cultivars. Crop Prot., 63, 26-35.

Boso S., Allonso-Villaverde V., Santiago JL., Gago P., Durenberber M., Duggelin M., 2010. Macro and microscopic leaf characteristics of six grapevine genotypes (Vitis spp.) with different susceptibilities to grapevine downy mildew. Vitis, 49, 43-50

Boso S., Gago P., Alonso-Villaverde V., Santiago J.J., Mendez J., Pazos I., Martínez M.C., 2011b. Variability at the electron microscopy level in leaves of members of the genus Vitis. Sci. Hort., 128, 228-238.

Brewer C.A., Smith W.K., 1997. Patterns of leaf surface wetness for montane and subalpine plants. Plant Cell Environ., 20, 1-11.

Carson S., Gray J.E., 2008. Influence of environmental factors on stomatal development. New Phytologist, 178, 9-23.

Carvalho L.C., Vidigal P., Amâncio S., 2015. Oxidative stress homeostasis in grapevine (Vitis vinifera L.). Front. Environ. Sci., 3, 20

Costa J.M., Ortuño M.F., Lopes C.M., Chaves M.M., 2012. Grapevine cultivars exhibiting differences in stomatal response to water deficit. Funct. Pl. Biol., 39, 179-189.

Denisov N.I., 1970. Anatomical and morphological study of Vitis amurensis. Sb. Tr. Asp., 17, 401-408.

Dickison W.C., 2000. Integrative plant anatomy. Harcourt Academic Press. San Diego. example - and the physiological behavior observed under field conditions.

\section{ACKNOWLEDGMENTS}

We would like to thank Telmo Nunes, Faculdade de Ciências da Universidade de Lisboa, for his technical assistance with SEM.

Doheny-Adams T., Hunt L., Franks P.J., Beerling D.J., Gray J.E., 2012. Genetic manipulation of stomatal density influences stomatal size, plant growth and tolerance to restricted water supply across a growth carbon dioxide gradient. Philos. Trans. R. Soc. Lond. B Biol. Sci., 367 (1588), 547-555.

Düring H., 1980. Stomata frequenz bei Blättern von Vitis-species und Sorten. Vitis, 19, 91-98.

Esau K., 1977. Anatomy of seed plants. $2^{\text {nd }}$ ed. John Wiley \& Sons, New York.

Eurostat, 2016. Agri-environmental indicator - consumption of pesticides. Eurostat statistics explains. $\mathrm{http} / /$ ec.europa.eu/eurostat/statistics-explained/index.php/Agrienvironmental indicator - consumption of pesticides

Flexas J., Scoffoni C., Gago J., Sack L., 2013. Leaf mesophyll conductance and leaf hydraulic conductance: an introduction to their measurement and coordination. J. Exp. Bot., 64 (13), 39653981.

Grammatikopoulous G., Manetas Y., 1994. Direct absorption of water by hairy leaves of Phlomis fruticosa and its contribution to drought avoidance. Can. J. Bot., 72, 1805-1811.

Gómez-del-Campo M., Ruiz C., Baeza P., Lissarrague J.R., 2003. Drought adaptation strategies of four grapevine cultivars (Vitis vinifera L.): modification of the properties of the leaf area. J. Int. Sci. Vigne Vin, 37, 131-143.

Hayat M., 1981. Principles and techniques of electron microscopy. Biological Applications. $2^{\text {nd }}$ ed. Ed. Arnold Publ. London.

He H., Veneklaas E.J., Kuo J., Lambers H., 2014. Physiological and ecological significance of biomineralization in plants. Trends Plant Sci., 19, 166-174.

Hegedüs A., 1974. Study of the epidermis of vine leaves. Acta Bot Acad Sci Hung, 20, 225-270.

IFV, 2007 Catalogue des variétés et clones de vigne cultivés en France. Institute Français de la Vigne et du Vin, Ministère de l'Agriculture et da la Pêche - CTPS, $2^{\text {ème }}$ edition. Montpellier, France.

IPCC, 2013: Climate change 2013: The physical science basis Contribution of working group I to the Fifth Assessment Report of the Intergovernmental Panel on Climate Change [Stocker, T.F., D Qin, G.-K. Plattner, M. Tignor, S.K. Allen, J. Boschung, A. Nauels, Y. Xia, V. Bex and P.M. Midgley (eds.)]. Cambridge University Press, Cambridge, United Kingdom and New York, NY, USA, $1535 \mathrm{pp}$.

IVV, 2017 Lista de castas. Instituto da Vinha e do Vinho, Ministério da Agricultura, Florestas e Desenvolvimento Rural. http://www.ivv.gov.pt/np4/111/, Accessed at 8 December 2017

Jones H.G., 2014. Plants and microclimate: A quantitative approach to environmental plant physiology. Cap. 10, Drought and other abiotic stresses, p. 255-289. $3^{\text {rd }}$ Ed., Cambridge University Press, Cambridge. 
Karabourniotis G., Kotsabassidis D., Manetas Y., 1995. Trichome density and its protective potential against ultra- violet-B radiation damage during leaf development. Can. J. Bot., 73, 376-383.

Keller M., 2010. The science of grapevines. Anatomy and physiology. Academic Press/Elsevier. $1^{\text {st }}$ edition, Burlington, MA. $377 \mathrm{p}$.

Lleras E., 1997. Differences in stomatal number per unit area within the same species under different micro-environmental conditions: a working hypothesis. Acta Amaz., 7, 473-476.

Lovisolo C, Perrone I, Carra A, Ferrandino A, Flexas J, Medrano H, Schubert A., 2010. Drought-induces changes in development and function of grapevine (Vitis spp.) organs and their hydraulic and non-hydraulic interactions at the whole-plant level: a physiological and molecular update. Funct. Plant Biol., 37, 98-116.

Martin T.J., Juniper, B.E. 1970. The cuticles of plants. Edward Arnold, London, $347 \mathrm{pp}$

Medri M.E., Lleras E., 1980. Aspectos da anatomia ecológica de folhas de Hevea brasiliensis Müell. Arg. Acta Amaz., 10, 463-493.

Metcalfe C., Chalk L., 1979. Anatomy of Dicotyledons, Vol I. $2^{\text {nd }}$ ed. Oxford Univ. Press.

Monteiro A., Teixeira G., Lopes C., 2013. Comparative leaf micromorphoanatomy of Vitis vinifera ssp. vinifera (Vitaceae) red cultivars. Ciência Tec. Vitiv., 28, 19-28.

Montoro A., López-Urrea R., Fereres E., 2016. Role of stomata density in the water use of grapevines. Acta Hort., 1115, 41-47.

Mott K., Gibson A., O'Leary J., 1982. The adaptive significance of amphistomatic leaves. Plant Cell Environ., 5, 455-460.

Nakata P., 2003. Advances in our understanding of calcium oxalate crystal formation and function in plants. Plant Sci., 164, 901-909.

Niinemets Ü., 1999. Components of leaf dry mass per area thickness and density - alter leaf photosynthetic capacity in reverse directions in woody plants. New Physiologist, 144, 35-47.

Niinemets Ü., Wright I.J., Evans J.R., 2009. Leaf mesophyll diffusion condutance in 35 Australian sclerohpylls covering a broad range of foliage structural and physiological variation. J. Exp. Bot., 60, 2433-2449.

Palliotti A,. Tombesi S., Frioni T., Famiani F., Silvestroni O., Zamboni M., Poni S., 2014 Morpho-structural and physiological response of container-grown Sangiovese and Montepulciano cv. (Vitis vinifera) to re-watering after a pre-veraison limiting water deficit. Funct. Plant Biol., 41(6), 634-647.

Parkhurst D.F., 1978. Adaptive significance of stomatal occurrence on one or both surfaces of leaves. J. Ecology, 66, 367-383.

Patakas A., Kofidis G., Bosabalidis A.M., 2003. The relationships between $\mathrm{CO}_{2}$ transfer mesophyll resistance and photosynthetic efficiency in grapevine cultivars. Sc. Hort., 97, 255-263.

Periyanayagam K., Kasirajan B., Karthikayan V., Gracelet R.J., Kumuda T., 2013. Quality assessment profile of the leaves of Vitis vinifera L. (Vitaceae). An important phytotherapy component of tropical diseases control. Innovare Journal of Health Sciences, 1, 26-31.

Pertot I., Caffi T., Rossi V., Mugnai L., Hoffmann C., Grando M.S., Gary C., Lafond D., Duso C., Thiery D., Mazzoni V., Anfora G., 2016. A critical review of plant protection tools for reducing pesticide use on grapevine and new perspectives for the implementation of IPM in viticulture. Crop Prot., 1-15.

Pratt C., 1974. Vegetative anatomy of cultivated grapes - a review. Am. J. Enol. Vitic., 25, 131-150.
Prychid C., Rudall P., 1999. Calcium oxalate crystals in Monocotyledons: A review of their structure and systematic. Ann. Bot., 84, 725-739.

Ruzin S.E., 1999. Plant microtechnique and microscopy. Oxford University Press. $322 \mathrm{p}$

Sadras V.O., Montoro A., Morana M.A., Aphaloc P.J., 2012 Elevated temperature altered the reaction norms of stomatal conductance in field-grown grapevine. Agr. For. Meteorol., 165, $35-42$.

Salisbury E.J., 1927. On the causes and ecological significance of stomatal frequency, with special reference to the woodland flora. Philosophical Transactions of the Royal Society of London, Series B 216, 1-65.

Santa Maria F.C.S., Marcide J.M.O., Organero, G.M., Torres, I.R., Barba, A.B., Rubio de Miguel C., Muñoz S.C., Sáiz R.S., 2011 Variedades de vid en España. Instituto Madrileño de Investigación y Desarrollo, Agrario y Alimentario. Editorial Agricola Española, S.A. Madrid. 489 pp.

Serra I., Strever A., Myburgh P., Schmeisser M., Deloire P.A., 2017. Grapevine (Vitis vinifera L. 'Pinotage') leaf stomatal size and density as modulated by different rootstocks and scion water status. Acta Hort., 1157, 177-181.

Soejima A.,Wen J., 2006. Phylogenetic analysis of the grape family (Vitaceae) based on three chloroplasts markers. Am. J. Bot., 93 , 278-287.

Swanepoel J.J., Villiers C.E., 1987. A numerical-taxonomic classification of Vitis spp. and cultivars based on leaf characteristics. S. Afr. J. Enol. Vitic., 8, 31-35.

Terashima I., Hanba Y.T., Tholen D., Niinemets U., 2011. Leaf functional anatomy in relation to photosynthesis. Pl. Physiol., 155, 108-116.

This P., Lacombe T., Thomas M.R., 2006. Historical origins and genetic diversity of wine grapes. Trends Genet., 22 (9), 511-519.

Tomás M., Flexas J., Copolovici L., Galmés J., Hallik L. Medrano H., Ribas-Carbó M., Tosens T., Vislap V., Niinemets Ü., 2013. Importance of leaf anatomy in determining mesophyll diffusion conductance to $\mathrm{CO}_{2}$ across species: quantitative limitations and scaling up by models. J. Exp. Bot., 64 (8), 2269-2281.

Tomás M., Medrano H., Pou A., Escalona J.M., Martorell S., Ribas-Carbó M., Flexas, J., 2012. Water use efficiency in grapevine cultivars grown under controlled conditions: effects of water stress at the leaf and whole-plant level. Aust. J. Grape. Wine. Res., 18 (2), 164-172.

Tombesi S., Nardini A., Farinelli D., Palliotti A., 2014 Relationship between stomatal behavior, xylem vulnerability to cavitation and leaf water relations in two cultivars of Vitis vinifera. Physiol. Plant., 152, 453-464.

Tooulakou G., Giannopoulos A., Nikolopoulos D., Bresta P., Dotsika E., Orkoula M.G., Kontoyannis C.G., Fasseas C., Liakopoulos G., Klapa M.I, Karabourniotis G., 2016. Alarm photosynthesis: calcium oxalate crystals as an Internal $\mathrm{CO}_{2}$ source in plants. Plt. Physiol., 171, 2577-2585.

Wilkinson H.P., 1979. The plant surface (Mainly Leaf). Part I: Stomata. In: Anatomy of Dicotyledons. Vol I. 98-117. $2^{\text {nd }}$ ed. Oxford Univ. Press.

Woodward F.I., Kelly C.K., 1995. The influence of $\mathrm{CO}_{2}$ concentration on stomatal density. New Phytologist, 131, 311-327. 